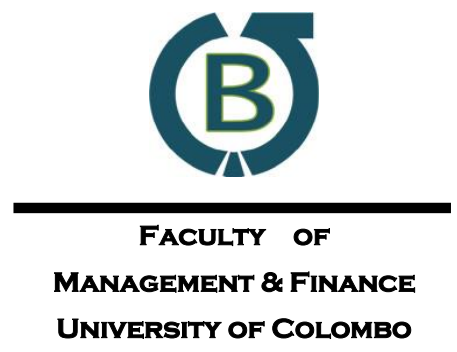

Colombo Business Journal

INTERNATIONAL JOURNAL OF

THEORY \& PRACTICE

Vol. 08, No. 01, June, 2017

\title{
Transformation of the Nature of Managerial Work in Modernity: Evidence from the Japanese Workplace
}

\author{
Akira Kimata $^{\mathrm{a} 1}$, Masayasu Takahashi ${ }^{\mathrm{b}}$ \\ ${ }^{a}$ Faculty of Economics, Niigata University, Japan \\ ${ }^{b}$ School of Business Administration, Meiji University, Japan
}

\begin{abstract}
The present study discusses modern managerial means and nature through telework, which has been viewed favourably for not only increasing white-collar productivity but also for improving work/life balance. In existing studies, the effect on society has been at the forefront of discussions while investigations about introductory methods or the actual conditions of telework are also active. However, there are few studies on conceptualization and the essential significance. For these reasons, this study will exactingly define the classifications and examine whether telework is a modern labour form in the context of "space-time" and "trust" and clarify the functions of organizational communication and leadership. Finally, we will present a research framework for further studies to comprehend the transformation of managerial nature from traditional work to modern telework through interviews with two Japanese information and communications technology companies.
\end{abstract}

Keywords: Telework, Space-time, Disembedding, Modernity, Leadership

\section{Introduction}

The expansion of electronic network accessibility and the growing availability of portable computers has meant that work can be performed almost anywhere. For example, salespeople, consultants, and researchers can work with the partial or complete replacement of commuting by using communications technology, and this way of working has been called "telework." Generally, telework is defined as the use of telecommunication to work outside the traditional 
office or workplace, usually at home or in a mobile situation. "Telecommuting," "flexible working," and "virtual working" have also been used to describe telework. The aim of the i-Japan Strategy 2015 from the Ministry of Land, Infrastructure, Transport and Tourism (MLIT, 2006), was to spread telework to 7 million people by 2015, while the New Information Technology Reform Strategy of 2006 cited one objective as increasing teleworkers to $20 \%$ of the working population. As such, telework has been viewed favourably not only in earlier research that attributes it to increased white collar productivity but also as a method of improving work/life balance and continuing work during pandemics, such as super influenza (e.g., Gordon \& Kelly, 1986; Huws, Korte, \& Robinson, 1990; Korte \& Wynne, 1996; Mitomo, 1997; Nilles, 1998; Lamond, 2000; Staples, 2001; MLIT, 2015).

The results of a private enterprise's global survey of approximately 3,000 workers in North America, Europe, the Middle East, Africa, and Asia Pacific showed that nearly $79 \%$ of the surveyed workers used teleworking at least 1 day per week, and nearly $62 \%$ of those chose a home office (Premiere Global Services Inc., 2015). Conversely, a large-scale investigation of global teleworkers by the public institution European Telework Development (1999) estimates that the status of the spread of telework in 1999 was 6.69 million people in the European Union (EU), 15.7 million in the United States, and 2.09 million in Japan. The percentage of teleworkers out of the whole workforce was the highest in the EU in the Netherlands (18.2\%), followed by Denmark (11.6\%), Finland (10.0\%), and Sweden $(9.0 \%)$. The number of teleworkers in the United States in 1999 was more than double that of the entire EU and represented $12.9 \%$ of the workforce. The proportion of teleworkers in Japan was $7.9 \%$ in the same year. Evidence suggests a number of factors combined to spur such explosive growth; these include the rising number of dual-career and single-parent households, and corporations responding to employees needs not only to excel in their jobs but also to remain an essential part of their families' lives (Golden, 2009).

However, according to telework population estimates within Japan by the MLIT (2015), the number of home-based teleworkers was 4.8 million, and the percentage of teleworkers as a total of the working population was only $8.3 \%$ in 2014 (see Figure 1) ${ }^{1)}$. In this statistical data, however, in addition to there not being a clearly unified concept of telework that can be said to be held in common, according to an interview survey by the authors, there was also the aspect that working from home was often at the trial run and experimental stages. We assume that one reason why telework did not spread in Japan in comparison with the EU or the United States was because of the influence of the Japanese collectivist work style and because telework has the traits of the process of "individualization" by fragmenting collectivity and producing exclusion (Taskin \& Devos, 2005). 
Figure 1. The Population of Japanese Home-Based Teleworkers

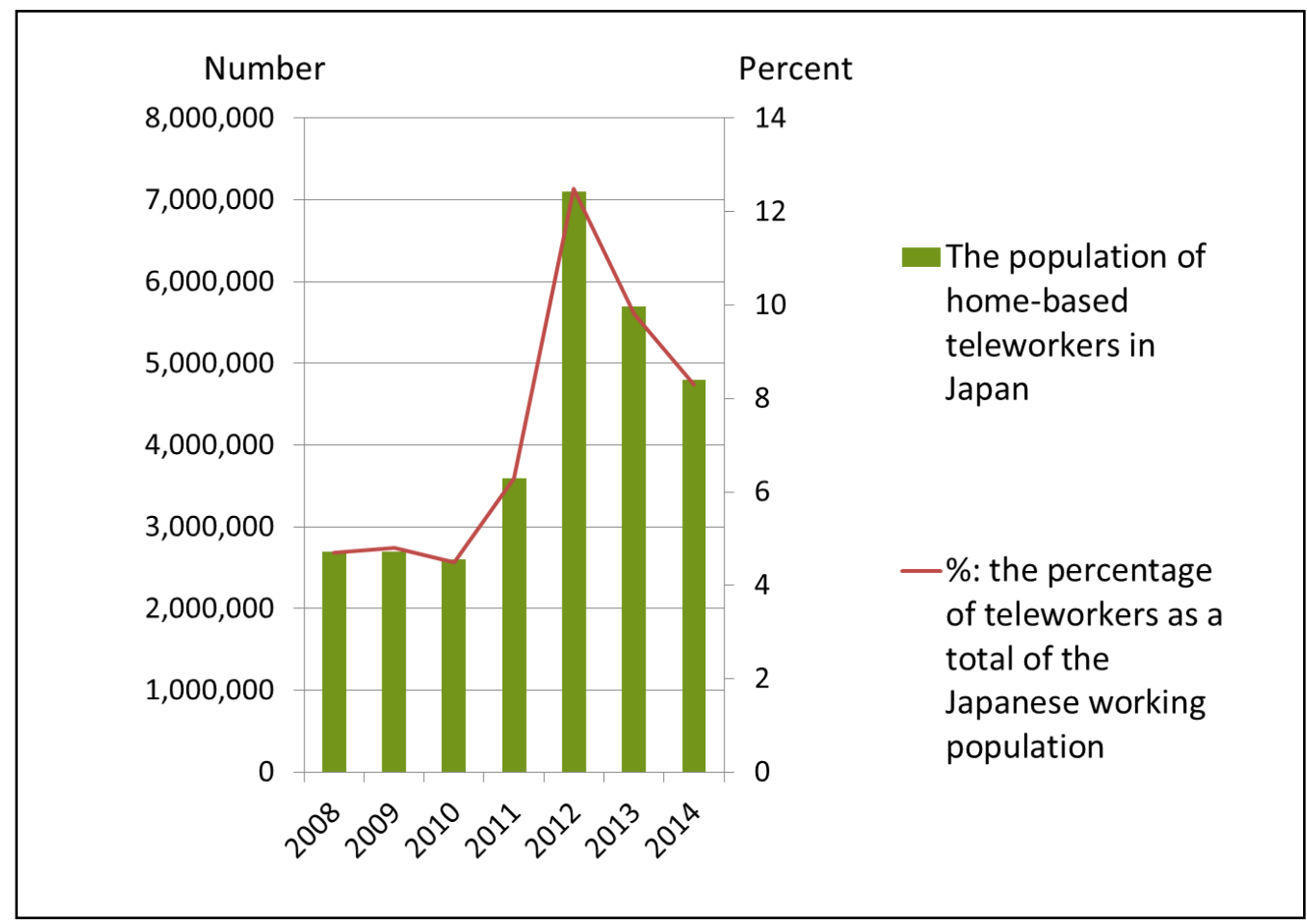

Source: The MLIT (2015)

In line with existing studies, the effect on society has been at the forefront of discussions. While investigations of the introductory methods or the actual condition of telework (e.g., Onishi, 1992; Mitomo, 1997; Spinks, 1998; Nilles, 1998; MLIT, 2006) and its influence on teleworkers' awareness, such as on autonomy, motivation, conflict or identity, and career success (e.g., Barsness, Diekmann, \& Seidel, 2005; Thatcher \& Zhu, 2006; Golden, 2007; Kreiner, Hollensbe, \& Sheep, 2009; Leslie, Park, \& Mehng, 2012) are also active, there are few studies on its conceptualization or the essential organizational perspective.

Our purpose here is to investigate the concept of telework, then clarify its traits of flexibility in time and space, while sorting and examining the classifications of telework. Further, this study examines telework as a modern labour form in the context of "space-time" (Giddens, 1987, 1990; Harvey, 1989) and "trust" (e.g., Luhmann, 1979; Yamagishi, 1998), and shows a research framework for further study through discourse with two Japanese information and communications technology (ICT) companies for the transformation of the nature of managerial work in modernity. 


\section{Definition and Classifications of Telework}

\section{Definition of the New Labour Form}

"Telework" is a synthesis of the prefix "tele," meaning "far," and "work." Its innovator was Toffler (1980), who proposed a third wave of human society that would be promoted by information systems using computers. He suggested that during the third wave, the scale of labour would be reduced and production would become scattered, in contrast to the concentration of labour forces in intensive offices and factories during the second wave. This meant a restoration of cottage industries, which meant labour forces would go back into their homes and hinted at white-collar homes becoming electronic cottages equipped with high-performance typewriters and fax machines, computer consoles, and video conferencing systems (Toffler, 1980).

Meanwhile, it was Nilles, Carlson, Gray, \& Hanneman (1976) who gave direction to telework research. They defined a new way of working where workers could "perform their work using communications and computer technologies at locations much closer to their homes" (Nilles et al., 1976 , p. 4), and taking corporate white collar workers as their subjects, they performed an experiment in which the workplace migrated to a work centre midway between the head office and employees' homes. That being said, however, Nilles et al. (1976) used the term "telecommuting" rather than "telework." This is the combination of the words "telecommunication" and "commuting" and speaks of a work situation that has conquered the communication gap between multiple locations by substituting commuting to work with communications technology and computers.

In related work, Mokhtarian (1991) designated telecommuting as working at home or at a place close to home during regular working hours instead of commuting to a traditional office and proposed two simple questions as the criteria in its definition: (a) Is there remote supervision? (b) Is the length of the commute trip reduced? In addition, Onishi (1992) defines telecommuting as on average working several days a week from either a satellite office or a home office without working in the head office (i.e., the place of work where the employee should essentially work) every day. In this way, telecommuting has been defined as white-collar employees replacing commuting with communications technology, in recognition of the ideas of the electronic cottage described by Toffler (1980) and the work centre (satellite office) described by Nilles et al. (1976). To put it another way, telecommuting is characterized by two points-flexibility in the location where work is done, and the use of electrical communication methods - and is a more limited concept than telework (Cross \& Raizman, 1986; Gordon \& Kelly, 1986; Mokhtarian, 1991; Onishi, 1992). 
Subsequent surveys and research (e.g., Electronic Commerce and Telework Trends [ECaTT], 1999) have indicated that telework includes not only something done by employees but also small

office and home office working means by entrepreneurs, as well as similar terms such as "networking," "remote working," and "flexible working" as described in the literature. As such, the definition of telework has become rather broad and complicated (see Table 1).

\section{Table 1: Definitions of Telework}

\begin{tabular}{|c|c|}
\hline Definition Details & Definition Proposer \\
\hline $\begin{array}{l}\text { Describes all activities concomitant with labor performed away from } \\
\text { employers and traditional offices for all or part of working hours, while } \\
\text { intending mutual communication of ideas between employer and } \\
\text { employee using telecommunication. }\end{array}$ & Gray, et al. (1993) \\
\hline $\begin{array}{l}\text { Teleworkers communicate with their employers and customers using e- } \\
\text { mail, phones, faxes, etc., by working at a location remote from the person } \\
\text { who pays the wages and payments; namely, in homes, (sales) } \\
\text { workplaces, or centers installed locally. }\end{array}$ & $\begin{array}{l}\text { The Telework, } \\
\text { Telecottage and } \\
\text { Telecentre Association } \\
\text { (TTTA, 1998) }\end{array}$ \\
\hline $\begin{array}{l}\text { Employees work all day ( }=1 \text { work unit) at a location remote from their } \\
\text { work superiors (satellite offices, home, etc.) while using electronic } \\
\text { communication and includes work performed according to the corporate } \\
\text { telework system, from frequency of every working day to the cases of } \\
\text { irregular implementation such as once a week or once a month. }\end{array}$ & $\begin{array}{l}\text { Telework Promotion } \\
\text { Conference (1996) }\end{array}$ \\
\hline $\begin{array}{l}\text { Offices and work systems that enable office workers for whom the city } \\
\text { center head office is essentially their place of work to work for some of } \\
\text { their office hours at a location remote from the head office, and a work } \\
\text { style arising from the viewpoint that flexibly identifies the office as a } \\
\text { place of intellectual production at the same time as viewing as important } \\
\text { the wealth and worth of the individual worker. }\end{array}$ & $\begin{array}{l}\text { Japan Satellite Office } \\
\text { Association (JSOA, 1998) }\end{array}$ \\
\hline $\begin{array}{l}\text { Anything that encompasses the concept of flexi-work used in the EU and } \\
\text { in Toffler's "electric homework" or, using the term of Nilles et al., } \\
\text { "telecommuting"(i.e., a type of labor that maintains flexibility of time } \\
\text { and location). Applies not only to employees but also to entrepreneurs } \\
\text { and small businesspeople. }\end{array}$ & Qvortrup (1998) \\
\hline
\end{tabular}

In this research ${ }^{2}$, which includes non-directive interviews based on qualitative analysis, it is particularly necessary to clarify the flexibility of telework in time and space. Broadly classified, we examine the interpretation of results based on what we felt were three unclear points:

(1) The problem of including employees and the self-employed as subjects: For example, while the Telework Promotion Conference (1996) defines teleworkers as employees, Qvortrup (1998) refers to teleworkers not only as employees but also as entrepreneurs 
and small-business people. He defines telework as all kinds of electronically mediated, work-related interactions across distance (Qvortrup, 1998).

(2) The problem of "time" insofar as whether working at a separate location from the traditional office for several hours a day can be defined as telework: For example, Gray, Hodson, \& Gordon (1993) do not limit the definition of time in telework to anything specific. This approach differs from that of MLIT (2015), which specifies the time as more than 1 minute a week.

(3) The problem of "space"3) insofar as where people work: This means that the definition of the location in telework has not been clarified. For instance, the Japan Satellite Office Association (JSOA, 1998) uses expressions such as "at a location remote from the head office," where the place of telework is unspecified.

\section{Classification by the Time-Space Perspective}

Spinks (1998) proposes the following three classifications according to the employment relationship in the broad definition while distinguishing between the broad and narrow definitions of telework: (1) employee teleworkers, (2) self-employed teleworkers, and (3) contracted teleworkers. Group (1) specifies people who are employed, and groups (2) and (3) are people who are independent and self-employed. Further, telework by employees in the narrow sense (i.e., employees who telecommute) describes a classification according to location and frequency. The following are indicated as classifications by location: (1) based at home, (2) based in an office (head office or satellite office), and (3) having a flexible base.

Classification (3) is a direct sales (choko-choki) style of working, and it also describes work styles that are highly mobile, in which the location where the work is performed is not fixed (Spinks, 1998). Full-time telework and part-time telework can be cited as classifications according to the frequency of use, where the former is teleworking every day without the employee going to the head office, and the latter is the case in which telework is performed in units of several times a week or month. Conversely, Nagasaka (1999) divides telework into 12 classifications along the two axes of employment and work style, and labour and task-supplying locations (see Table 2).

The classification into "micro-enterprises" and "non-business" is based on the format of the contract used, and employment type uses the frequencies of "full time" and "part time" as standard. Employment type is further classified into "all" or "partial" depending on whether the telework is performed on all working days or divided into daily or hourly units. By contrast, employee type is divided into "micro-enterprises," that is, small-scale personal businesses, and the "non-business" type, where having a side job or working to supplement the household income 
is considered. These four classifications are further subdivided into three types: home, satellite office (or small office in the case of telework by the self-employed), and the highly mobile direct sales style of working, leading to a total of 12 types. These classifications by Nagasaka (1999) clarify the X and Y axes while encompassing the earlier classification repertory of Spinks (1998) and can be said to be evaluated from the point of making the complex types of telework easier to understand for classification.

\section{Table 2: The Twelve Classifications of Telework}

\begin{tabular}{|c|c|c|c|c|}
\hline \multirow{2}{*}{\multicolumn{2}{|c|}{ Employment and Work Style }} & \multicolumn{3}{|c|}{ Labor and Task-Supplying Location } \\
\hline & & Home & STO/SMO & Mobile \\
\hline \multirow[t]{2}{*}{$\begin{array}{l}\text { Employment } \\
\text { Type }\end{array}$} & All & $\begin{array}{l}\text { All work done at } \\
\text { home }\end{array}$ & All STO working & All mobile work \\
\hline & Partial & $\begin{array}{l}\text { Work partially } \\
\text { done at home }\end{array}$ & Partial STO working & Partial mobile work \\
\hline $\begin{array}{l}\text { Non-Employ- } \\
\text { ment Type }\end{array}$ & $\begin{array}{l}\text { Business Type } \\
\text { Non- } \\
\text { Business Type }\end{array}$ & $\begin{array}{l}\text { Working at home } \\
\text { Working at home } \\
\text { (side job) }\end{array}$ & $\begin{array}{l}\text { SMO micro- enterprise } \\
\text { SMO self- } \\
\text { employed type }\end{array}$ & $\begin{array}{l}\text { Mobile work } \\
\text { Mobile work }\end{array}$ \\
\hline
\end{tabular}

Note: STO means "Satellite Office", and SMO means "Small Office" Source: Nagasaka (1999), p. 57.

Nevertheless, with the classification of Nagasaka (1999), entities not established by a corporation at its own expense, such as entities called "public telework centres" that are established by the local government, and entities called "spot offices," which are run by firms as sites where sales occur or sales people use mobile devices, are excluded. The public telework centres and spot offices are functional equivalents when compared to satellite offices, which are established independently by companies, from the point of both being telework facilities that are different from the head office in Japan.

In the present research, we identify public telework centres and spot offices by classifying them same as satellite offices. However, to avoid confusion, the classification designated "STO" by Nagasaka (1999) is called a "work centre" as per Nilles et al. (1976). Further, the subjects of this research, which focuses on telework by the employees of private enterprises, are arranged by describing them on the two axes of time and space as shown in Table 3. Thus, by classifying telework according to the time-space perspective, our study can holistically show the essence of telework that is regarded as the flexibility of time and location by Qvortrup (1998) and others. Further, in the spatial flexibility, as Lähteenmäk (2002) has stated, the physical location of the work is individually negotiated and varies according to the needs of the task in most cases. 
Table 3: Classifications of Time-Space Perspective

\begin{tabular}{|c|c|c|c|}
\hline Space & Home & Work centre & $\begin{array}{l}\text { Mobile (outside } \\
\text { the company) }\end{array}$ \\
\hline \multicolumn{4}{|l|}{ Time } \\
\hline All work-days & $\begin{array}{l}\text { Always at } \\
\text { home }\end{array}$ & $\begin{array}{l}\text { Always at work } \\
\text { centre }\end{array}$ & Always mobile \\
\hline Daily or hourly units & Partly at home & $\begin{array}{l}\text { Partly at work } \\
\text { centre }\end{array}$ & Partly mobile \\
\hline
\end{tabular}

\section{Traits of Time-Space in Modernity}

In the previous section, we presented a framework that explicitly incorporated the time-space perspective in the telework classification. In this section, we investigate the kind of theoretical conceptualization and essential significance that can be constructed in the context of modernization. Then, we focus on the concept of "space-time" (Giddens, 1984, 1990; Harvey, 1989) and "disembedding" (Giddens, 1990).

According to Giddens (1990, p. 22), the "shifting alignments of time and space" are of primary importance to the nature of modernity in particular. In pre-modern cultures, time was imprecise and always linked with place. Space and place, which refer to something "local," largely coincide. The spread of the mechanical clock uniformly expressed time as an empty dimension and qualified it in such a way as to permit the precise designation of zones of the day. Electronic media separate presence in time from presence in space, and each expands "time-space distanciation" (Giddens, 1984, p. 203). The advent of modernity tore time away from place and space away from place. The "empting of time" was the precondition for the "empting of space" (Giddens, 1990, p. 18). As a result, the transformation of space by "embedding" activities fostered relations between "absent" others, which are spatially distant from any given situation of face-to-face interaction. In modern societies, the constriction of space-time results in confused roaming (Harvey, 1989) and serves to open up manifold possibilities for change by breaking it free from the restraints of local habits and practices. Further, Giddens (1990, p. 21) proposes the concept of "disembedding,"4) which means the lifting out of social relations from local contexts of interaction, in other words, the means of space-time distanciation and their restructuring across indefinite spans of space-time.

Based on Giddens's argument, Sahay (1997) discusses a framework in which meanings of time-space are deeply embedded within social structure, and ICT, through its capability to create new time-space conditions for social interaction, impinges on the material ordering of our daily 
lives and "the associated feelings of inclusion and presence with respect to the social system." This means that the influence of ICT should be redefined by the interaction of technology. Also, Brocklehurst (2001) discusses the identity and subjectivity of the home-based teleworker and divides previous studies into pessimism (including Giddens) and optimism. The results of his research indicate that the restructuring of space and time caused considerable "anxiety" in teleworkers to recreate the very same rules of the traditional office and to create a new selfidentity as workers. His suggestion is meaningful because of the standpoint of the critical interpretation.

On the other hand, Sato (2006, p. 34) explains that in telework, labour is "disembedding." That is, separating from the fixed office and "relations with employees who are not there" is promoted. The teleworking place, a seat on a train or a sofa in a home, is not an office but a space for labour. In this sense, labour through telework is cut off from the context of time-space and recombined in a different context (Sato, 2006). In terms of the free arrangement of labour through the separation and the recombination of time-space, it is reasonable to suppose that telework is yielded by modernization. To examine the organizational consequence of modernity, next we will begin by arguing the managerial means and nature of telework through two interviews.

\section{Methods}

\section{Data Collection}

The interview methods are broadly divided into the directive method and the nondirective method. The present study employed the nondirective interview method so we can clarify and explore a few specific aspects of the events. The nondirective method has some disadvantages; for instance, the content of the interview questions tends to fall into a stereotype, and the results can be affected by the skills of the interviewer. In order to ensure the reliability of the interview method and the validity of the results, Yin (1994) emphasized (a) maintaining the chain of evidence, (b) creating an interview database, and (c) using multiple sources of evidence. The present study was conducted based on these three principles proposed by Yin to avoid possible demerits caused by the nondirective method. We created an interview database and expressly confirmed the facts with every subject by email and telephone to secure the reliability of the chain of evidence.

\section{Research Context}

Further, for the present interviews, we searched for cases where generally listed companies or non-generally listed companies had been officially commended as excellent precedents by the Japan Telework Society Conference. As mentioned, we interviewed several companies that had 
adopted teleworking and for this paper extracted two typical companies. Net One Systems Co., Ltd (Tokyo, Japan) is an example of a generally listed company, and DUNKSOFT Co., Ltd (Tokyo, Japan) is an example of a non-generally listed company. We indicate our samples ${ }^{5)}$ in Table 4.

Table 4: Two Samples of Adopting Telework

\begin{tabular}{|c|c|c|}
\hline & $\begin{array}{l}\text { Net One Systems Co., Ltd (Tokyo, } \\
\text { JAPAN) }\end{array}$ & $\begin{array}{l}\text { DUNKSOFT Co., Ltd (Tokyo, } \\
\text { JAPAN) }\end{array}$ \\
\hline $\begin{array}{l}\text { Business } \\
\text { Description }\end{array}$ & $\begin{array}{l}\text { Building and consulting ICT } \\
\text { infrastructure }\end{array}$ & $\begin{array}{l}\text { Designing websites and building } \\
\text { homepages, improving business } \\
\text { efficiency in ICT (information and } \\
\text { communication technology) }\end{array}$ \\
\hline Foundation & 1988 & 1983 \\
\hline Capital & 12,279 million yen( March 2013) & 10 million yen (January 2017) \\
\hline Employees & 2,210 (Consolidated basis, March 2013) & 25 (January 2017) \\
\hline Net sales & $\begin{array}{l}\text { 141,421 million yen(for the year ended } \\
\text { March, 2013) }\end{array}$ & $\begin{array}{l}220 \text { million yen(for the year ended June, } \\
2012 \text { ) }\end{array}$ \\
\hline Net income & $\begin{array}{l}\text { 4,324 million yen(for the year ended } \\
\text { March, 2013) }\end{array}$ & - \\
\hline
\end{tabular}

The business description for Net One Systems is ICT infrastructure building and consulting. The company was founded in 1988 and employed 2,210 persons as of March 2013. The working environment in the company around 10 years ago was difficult. The office overflowed with documents and personal belongings. Employees were working until midnight, and the resignation rate was high. In order to improve the working environment, productivity, and employee satisfaction, the company implemented institutionalized teleworking from spring 2011 and applied a free address system to all employees from April 2014. Of the aforementioned spacetime categories, Net One Systems widely adopted flexible telework by daily or hourly units at home, at a work centre, or in a mobile situation. As various events and ITC-related workshops were held in open spaces at the head office, an informal organization was actively formed to create connections among employees.

Conversely, the business description of DUNKSOFT is designing websites, building homepages, and improving business efficiency in ICT. The company was founded in 1983 and employed 25 persons by January 2017. The head office of this company is in Tokyo and has a satellite office in Tokushima, situated in the Shikoku region approximately 300 miles west of Tokyo. Four employees always engage in home-based telework at Tokushima, Kanagawa, and 
Tochigi. Among previously mentioned categories, DUNKSOFT introduced telework with high flexibility in time-space to allow employees to work at home or at a work centre far from the head office for the long term. Several employees work using personal computers and meet with business partners at the satellite office in Tokushima, which was remodelled from an old private house.

\section{Discourse of Managerial Means and Nature}

The manager of the human resources department at Net One Systems said the following:

We introduced a working style that was flexible regarding location. In personnel evaluations, employees used to be measured by time and their processes, but now, they are assessed by results. We have adopted not only teleworking but also a discretionary labour system and a flex-time system simultaneously. Employees can perform telework in units of 1 day or a half day. Employees who engage in telework must get permission from their immediate supervisor and provide concrete results for what they have planned. They have to report to their boss via email when starting and stopping work. As the teleworker is invisible, personnel management relies on selfassessment by the employee. Teleworking is an institution based on trust between a manager and a subordinate. Of course, there are a few employees who may abuse the teleworking institution, but we think it is only a small percentage that can be safely ignored. Because the original purpose of telework is to raise the autonomy and motivation of employees, a strict monitoring ICT system for teleworkers has no significance. We think the institutional design should build in a belief in the innate goodness of man. As a result, the total consolidated sales increased by $20 \%$ from the previous year, while overtime work decreased by $2 \%$ and the employee turnover rate fell to around $4 \%$ per year.

The executive of DUNKSOFT provided the following explanation:

Approximately 15 years ago, I thought that organizational change was necessary for the sustainable growth of our company. My image of the new organization was that every member plays a "polyvalent" role, where one plays three roles as a creator, programmer, and salesmen by having autonomous motivation. I decided to fix the working environment. At that time, a male employee proposed home-based telework due to severe atopic dermatitis. But this was a problem as telework would prevent the appropriate communication among employees. Japanese show consideration for somebody's feelings through face-to-face interaction in the same workplace. We keep "anshin," which means a feeling of belonging with each other. To solve this problem, I introduced the Business for Skype teleconference system by Microsoft. Generally, an organization uses a teleconference system only when it is needed. However, our system is constantly connected to a server in order to continuously project all workplaces on one screen so that every member can talk with each other online like talking as a neighbourhood (see Figure 2). In this company, the working conditions of all employees, for example, teleworkers in home offices and workers in the head office, are projected on this screen and shared at all workplaces. Some members may think they are being watched in the working environment. But, actually, almost all employees are 
fond of the boss keeping an eye on their good work. Lately, a female employee is teleworking due to childbirth and child care, and now, around four employees regularly engage in home-based telework. It is difficult for a small company such as DUNKSOFT to hire excellent and talented workers in Tokyo. If there were excellent creators whose family circumstances were such that they would move to a regional city out of necessity, our company would make a satellite office there to hire them.

\section{Figure 2. Working Condition of Employees in DUNKSOFT}

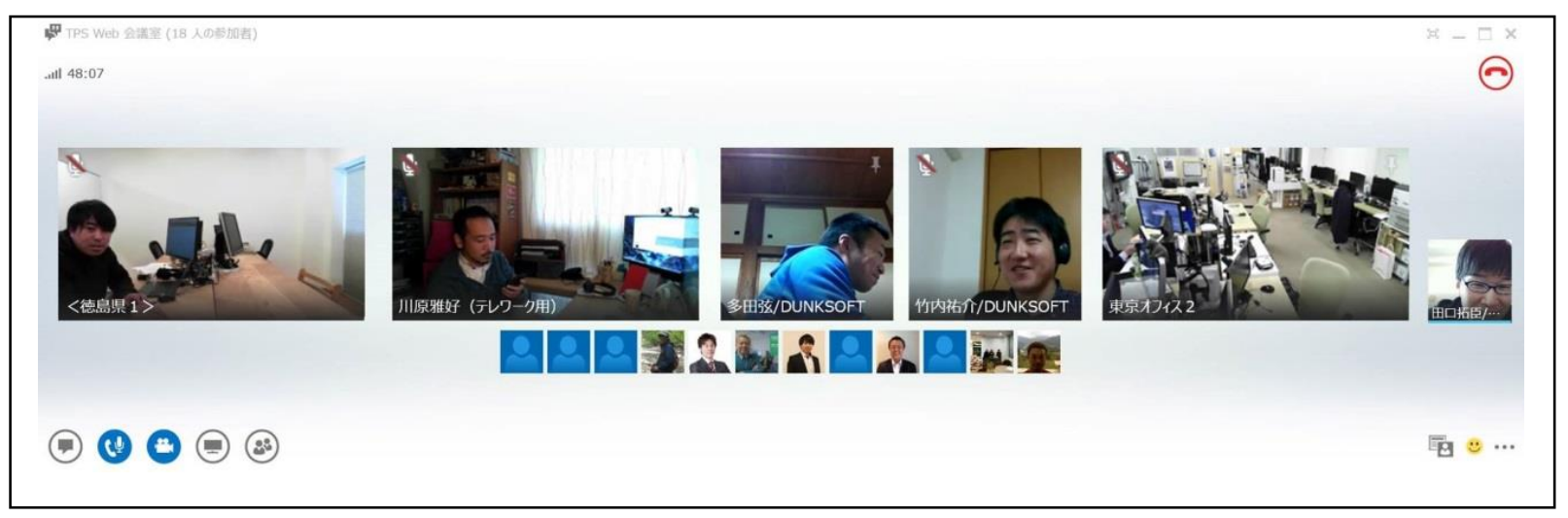

Source: Photo by DUNKSOFT, Photography by Yojiro Kuroyanagi

\section{Theoretical Interpretation of the Discourse}

\section{The Two Clues of Interpretation}

To interpret the above discourse, we again seek clues in the context of the argument of Giddens's modernity. He shows that Max Weber concentrated his attention upon the transition from personal types of affiliation to impersonal rules in the development of bureaucracy, but there is another implication of "the zoning of space-time" (Giddens, 1987, p. 163). Control is accomplished in traditional organizations through direct supervision and sanctioned force, but in offices separated from one another in time-space, impersonal procedural rules can serve as a substitute. Further, Giddens (1987, p. 165) explains that "trust upon individuals to adopt impersonal procedural rules" is unavoidably necessary. Actually, in the discussions of homebased telework, a home is a particular type of social space that is not only a site of production but also a site of social reproduction and consumption (e.g., Kaufman-Scarborough, 2006; Sewell \& Taskin, 2015), and in the contexts, it is insisted that professional teleworkers are reordered for reshaping along norms, i.e., trust in the traditional workplace (Sewell \& Taskin, 2015). It may be said that their suggestion provides an additional explanation for Giddens's perspective. Following the studies, we decided to focus our attention on "trust upon individuals" as the first clue for interpreting our discourses. 
Conversely, Giddens (1990) mentions that the basic institutional dimensions of modernity are capitalism, industrialism and surveillance, and military power, and in surveillance, typical supervision is indirect through administrative power. In particular, we examine the above discourse with the second clue of "surveillance," which has a strong relationship with modern managerial means. Uniting the arguments above, the transformation of managerial means from traditional work to modern telework along the time-space flexibility can be shown in Figure 3.

\section{Figure 3: An Assumption for Transition of Managerial Means}

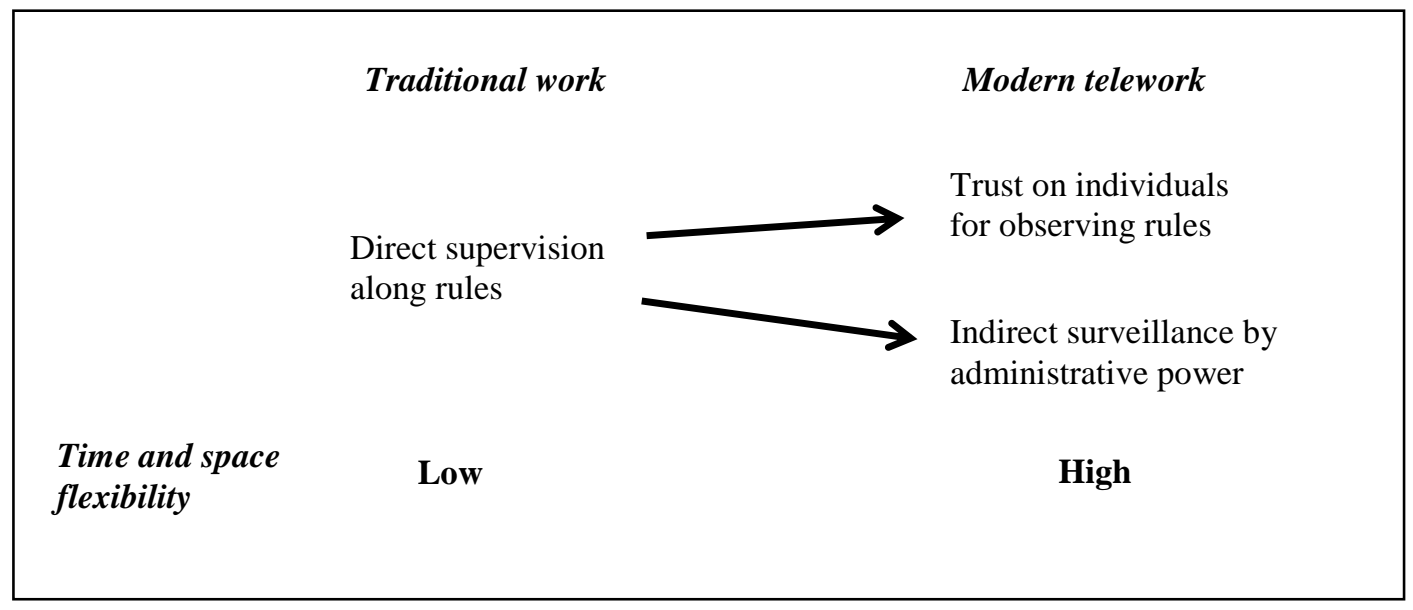

However, there are various views on the concept of trust, so it is necessary for us to examine further studies in detail. Huff \& Kelley (2003) examine trust in individualist culture and collectivist culture and point out that Japan is often used as a cultural model for fostering trust and cooperation. They show that the Japanese concept of " $w a$," or harmony, involves sharing, cooperation, warmth, and fellowship leading to trust in a work relationship. Originally, conventional studies on trust examined whether objectives were individual or collective.

Meanwhile, Luhmann (1979, p. 4) states: "Trust, in the broadest sense of confidence in one's expectations, is a basic fact of social life." He explains trust in the context of a "reduction of complexity" in the social system and formulates it in the three dimensions. Familiarity is the foundation of trust. As the degree of world complexity increases, we cannot cope with everything only as interpersonal-trust, and system-trust ${ }^{(6)}$ becomes indispensable for human life. Here, if we quote Luhmann's classification, system-trust covers the expectation of stability in the ICT and network system, and interpersonal trust covers the expectation that teleworkers will observe the rules. Furthermore, as in the suggestion of Huff \& Kelley (2003), we should especially incorporate Japanese collectivism in interpersonal trust. 
Gundlach, Zivunska, \& Stoner (2006) show that collectivists' views group interests as more important than individual needs, even when such actions sometimes require sacrificing personal interests, and individualistic organizational members negatively influence organizational performance. They suggest the dimension of individualism-collectivism influences the organizational meta-perception accuracy of members because collectivists focus on monitoring and maintaining their relationships rather than on ego protection (Gundlach et al., 2006).

Conversely, Yamagishi (1998), a social psychologist, asserts that Japanese collectivism comes not from a mental property that prioritizes group interests over personal ones; rather, it is a social mechanism that, in particular, uses mutual supervision and regulation through face-to-face interaction to prevent people from acting against group interests. Building on the arguments by Luhmann (1979), Barber (1983), and various Japan-United States research findings, Yamagishi (1998, 1999) demonstrates that there are two sides to interpersonal trust. The first is the expectation of others based on human nature and the characteristic of behaviour, called primary trust. The second is peace of mind achieved by preventing people from acting against group interests, known as the Japanese concept of "anshin," or relief; that is, the expectation of others based on the long-term calculation of mutual loss and gain. The stability of the organizational system was maintained through anshin, which controlled selfish actions internally until now, and interfered with the development of primary trust (Yamagishi, 1999). Finally, he emphasizes that the globalization of commerce, the progress of ICT, and the collapse of the lifetime employment system and the local community have eroded the stable and closed concept of anshin in the Japanese organizational system.

\section{Assumption for the Managerial Nature}

In the previous section, we presented the two clues and the concept of trust, including primary trust and anshin. Along the theoretical overviews, how can we interpret the two discourses?

Net One Systems introduced teleworking through strict procedural rules. The manager of the human resources department of the company said, "As the teleworker is invisible, personnel management relies on self-assessment by the employee." He explained further, "Teleworking is an institution based on the trust between a manager and a subordinate". An important point to emphasize is that the company thought performance depended on trusting their teleworkers. We can identify the discourse of introducing telework with respect to the first clue of "trust upon individuals" to adopt impersonal procedural rules. Also, we should specify that the concept of trust means "primary trust" because the manager said that the institutional design should build in a belief in the innate goodness of man. ${ }^{7)}$ 
Conversely, DUNKSOFT utilized a teleconference system to watch its employees. Taken in the light of modernity, we can identify the discourse of introducing telework with respect to the second clue of "indirect surveillance of administrative power" being reinforced by progressive ICT. However, it is rash to conclude that supervision by ICT was indirect and based on administrative power.

First, almost every enterprise uses a teleconference system, but, in general, only when it is needed. However, at DUNKSOFT, the system is constantly connected to a server to continuously project all workplaces on one screen. The president of the company said that home-based telework had the problem of preventing appropriate communication among employees. This is of particular importance to the Japanese especially since they show consideration for a person's feelings through face-to-face interaction in the same workplace. To solve this problem, he introduced the constantly connected teleconference system. Thus, we can consider it not as indirect supervision but as direct and participative supervision because employees communicate by virtual face-to-face interaction to "read" their feelings of each other. Further, as Cleavenger \& Munyon (2015) show, we can interpret that the system plays a role in stimulating a help-seeking response to cooperate for the achievement of goals in the organization because ICT removes much of the richness of the communication channel compared to face-to-face interactions.

Second, the president of the company mentioned that the leader should keep anshin (a feeling of belonging with each other) in the organization. The function of the teleconference system is not only to use administrative power to check the working behaviour of the employees but also to achieve anshin among employees to control selfish actions internally. Also, we can interpret that the teleconference system fulfils the role of a "situational enhancer of inspirational leadership" (Joshi, Lazarvova, \& Liao, 2009, p. 249), which makes up for the lack of a shared context and spontaneous communication in highly dispersed organizational structure. So, to summarize, we can conclude that our research yields the following research framework for further studies, abstracting two trends of managerial nature in time and space in a highly flexible condition (see Figure 4).

The first trend of managerial nature is organizational belief based on "primary trust" as the foundation for human relations, which is the consequence of Western modernity. The second trend of managerial nature is organizational belief based on anshin by "direct and participative supervision" using progressive ICT. We should assume that, this is the result of Japanese cultural diversity rather than the consequences of Western modernity because the term of anshin among employees is one of externalization of Japanese collectivism 
Figure 4: Two Types of Modern Managerial Nature and Means in High Flexibility

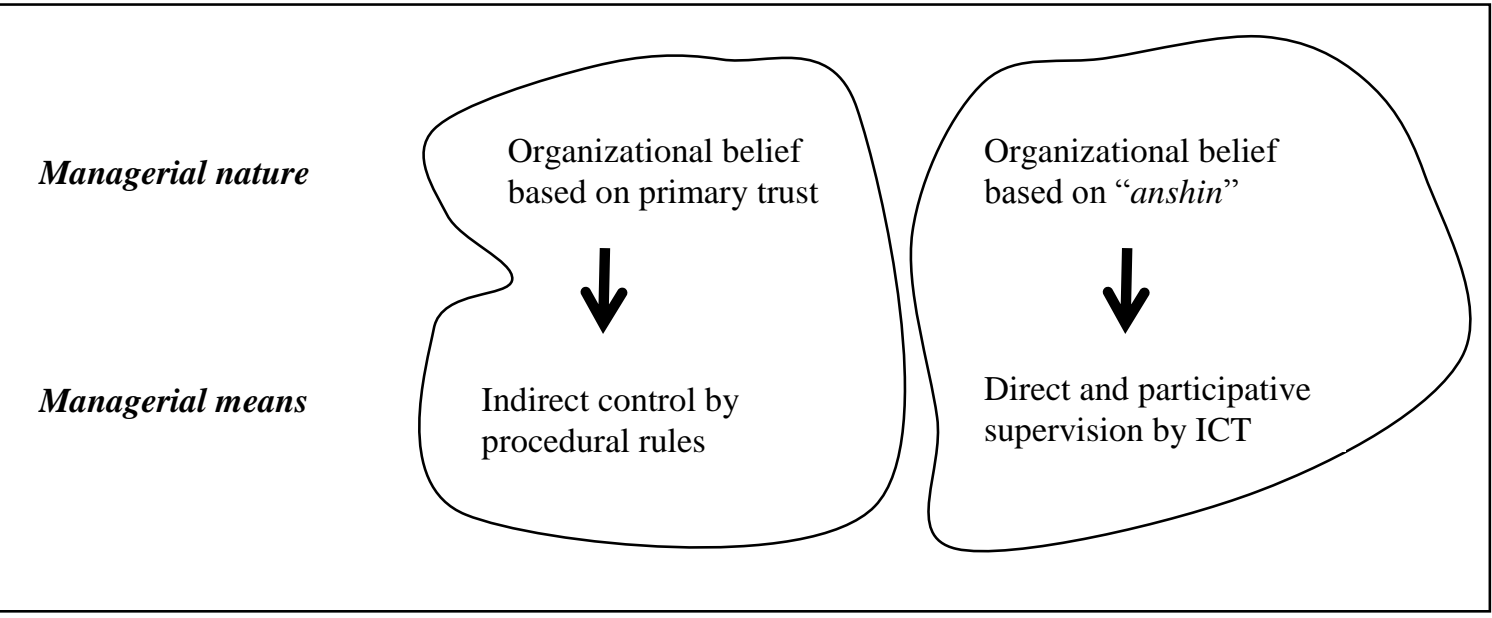

\section{Conclusion}

In this study, we examined the transformation of managerial means and nature through modern labour forms of telework. As the present research was limited to a small sample of two Japanese ICT companies, there is a limit to the broader applicability of it. However, we believe the results have indicated several contributions.

Firstly, the present study defined the concept of telework, and then clarified its traits of flexibility in the time-space perspective while sorting and examining the classifications of telework. Although previous studies have shown various, complicated categorizations of telework, we proposed a simple and well-covered framework of telework according to the actual modern situation. This is a theoretical and practical contribution of this study.

Secondly, we pointed out an analogy between our actual framework and the concept of spacetime (Giddens, 1987, 1990; Harvey, 1989) and proposed a research framework for further studies abstracting the transformation of managerial means and nature in Western modernity. According to the discourses of two Japanese ICT companies, there are two trends of managerial nature when the transition from a traditional labour form to modern telework brings high flexibility in timespace:

(1) The organizational belief based on primary trust as the foundation for human relations, which is the consequence of Western modernity.

(2) The organizational belief based on anshin by direct and participative mutual supervision using progressive ICT. We assume this is the result of Japanese cultural diversity because 
the term of anshin among employees is one of externalization of Japanese collectivism. This is a theoretical and empirical contribution of the present study.

However, there are some limits to the scope and scale of this study. To overcome them, we should go on to develop our framework by reviewing the new literature and extending the original investigations to other Japanese companies that have adopted teleworking. Also, a foreseeable extension of this research would be to include comparisons with the managerial nature in Asian countries, the United States, and the European Union because the implication of this study is derived as yet from a local characteristic context.

\section{Content Endnotes}

1) The investigation defines a teleworker as an employee who engages in home-based telework for more than 1 minute a week. In 2012, the number of teleworkers sharply increased because a mega-earthquake in the Tohoku area of Japan generated a tsunami that caused an accident at the Fukushima nuclear power plant and significantly affected the commuting and business activities of many people.

2) We conducted the telework interviews for several companies, that is, publicly listed companies with pharmaceutical, education, consumer electronics, and ICT building or consulting business descriptions from April 2011 to June 2015.

3) According to Wilson, O'Leary, Metiu, and Jett (2008), there is a paradox between geographical distance and perceived distance. Although they suggest the significance of perceived proximity in virtual work, the latter cannot be treated in the present study.

4) Giddens (1990, p. 26) insists that "disembedding mechanisms" consist of the creation of "symbolic tokens" and the establishment of "expert systems" that depend upon "system trust."

${ }^{5)}$ We conducted the interviews with the manager of the human resources department at the head office of Net One Systems in October 2012 and March 2015, and the president of DUNKSOFT at the company's satellite office in June 2015.

${ }^{6}$ System-trust is what Giddens (1990) calls the trust in the expert system.

7) Although we observed several companies that introduced telework based upon trust in individuals through strict procedural rules like Net One Systems, we extracted the typical case in this paper.

\section{Acknowledgements}

This work was supported by Kitano Foundation of Lifelong Integrated Education and KAKENHI Grant Number 17K03870. Further, the authors wish to thank Net One Systems and DUNKSOFT for their support.

\section{References}

Barber, B. (1983). The logic and limits of trust. New Jersey, USA: Rutgers University Press. 
Barsness, Z. I., Diekmann, K. A., \& Seidel, M. L. (2005). Motivation and opportunity: The role of remote work, demographic dissimilarity, and social network centrality in impression management. Academy of Management Journal, 48(3), 401-419.

Brocklehurst, M. (2001). Power, identity and new technology homework: Implications for 'new forms' of organizing. Organization Studies, 22(3), $445-466$.

Cleavenger, D. J., \& Munyon, T. P. (2015). Overcoming the help-seeker's dilemma: How computer-mediated systems encourage employee help-seeking initiation. Organization Studies, 36(2), 221-240.

Cross, T. B., \& Raizman, M. B. (1986). Telecommuting. Illinois, USA: Richard D. Irwin.

Electronic Commerce and Telework Trends (1999). Telework in Europe 1999. Retrieved October 23, 2002, from http://www.eto.org.uk/ twork/tw99/index.htm.

European Telework Development (1999). European telework development estimates 1998-1999. Retrieved October 23, 2002, from http://www.eto.org.uk/twork/ tw99/index. htm.

Giddens, A. (1984). The constitution of society. California, USA: The University of California Press.

Giddens, A. (1987). Social theory and modern sociology. California, USA: Stanford University Press.

Giddens, A. (1990). The consequences of modernity. Cambridge, UK: Polity Press.

Golden, T. D. (2007). Co-workers who telework and the impact on those in the office: Understanding the implications of virtual work for co-worker satisfaction and turnover intentions. Human Relations, 60(11), 1641-1667.

Golden, T. D. (2009). Applying technology to work: Toward a better understanding of telework. Organization Management Journal, 6, 241-250.

Gordon, G. E., \& Kelly, M. M. (1986). Telecommuting: How to make it work for you and your company. New Jersey, USA: Prentice-Hall.

Gray, M., Hodson, N., \& Gordon, G. E. (1993). Teleworking explained. New York, USA: John Wiley \& Sons.

Gundlach, M., Zivunska, S., \& Stoner, J. (2006). Understanding the relationship between individualism-collectivism and team performance through an integration of social identity theory and the social relations model. Human Relations, 59(12), 1603-1632.

Harvey, D. (1989). The condition of postmodernity: An enquiry into the origins of cultural change. Oxford, UK: Blackwell Publishing.

Huff, L., \& Kelley, L. (2003). Levels of organizational trust in individualist versus collectivist societies: A seven-nation study. Organization Science, 14(1), 81-90.

Huws, U., Korte, W. B., \& Robinson, S. (1990). Telework: Towards the elusive office. New York, USA: John Wiley \& Sons. 
Japan Satellite Office Association (1998). テレワーク白書 [Telework white paper]. Tokyo, Japan: Author.

Joshi, A., Lazarvova, M. B., \& Liao, H. (2009). Getting everyone on board: The role of inspirational leadership in geographically dispersed teams. Organization Science, 20(1), 240252.

Kaufman-Scarborough, C. (2006). Time use and the impact of technology: Examining workplaces in the home. Time \& Society, 15, 57-80.

Korte, W. B., \& Wynne, R. (1996). Telework: Penetration, potential and practice in Europe. Amsterdam, the Netherlands: ISO Press.

Kreiner, G. E., Hollensbe, E. C., \& Sheep, M. L. (2009). Balancing borders and bridge: Negotiating the work-home interface via boundary work tactics. Academy of Management Journal, 52(4), 704-730.

Lähteenmäk, S. (2002). Flexible working in Finland - Sign of new IR or just the opposite? In I. U. Zeytinoglu (Ed.), Flexible work arrangements: Conceptualizations and international experiences (pp. 221-239). The Hague, The Netherlands: Kluwer Law International.

Lamond, D. A. (2000). Organizational structures that support telework. In K. Daniels, D. A. Lamond, \& P. Standen (Eds.), Managing telework (pp. 21-29). London, UK: Business Press.

Leslie, L. M. B., Park, T., \& Mehng, S. A. (2012). Flexible work practices: A source of career premiums or penalties? Academy of Management Journal, 55(6), 1407-1428.

Luhmann, N. (1979). Trust and power: Two works. Chichester, UK: John Wiley \& Sons.

Luhmann, N. (1988). Familiarity, confidence, trust: Problems and alternatives. In D. Gambetta (Ed.), Trust: Making and breaking cooperative relations (pp. 94-107). Oxford, UK: The University of Oxford.

Mokhtarian, P. L. (1991). Defining telecommuting. Transportation Research Record, 1305, 273281.

Mitomo, H. (1997). テレワーク社会[Telework society]. Tokyo, Japan: NTT Publications.

Nagasaka, T. (1999). 情報化に伴うテレワーク・在宅勤務の現状と可能性 [The current state and possibilities of telework and home-based working concomitant with informatization]. 日本労働研究雑誌, 41(6), 56-63.

Nilles, J. M. (1998) Managing telework: Strategies for managing the virtual workforce. New York, USA: John Wiley \& Sons.

Nilles, J. M., Carlson, F. R., Gray, P. Jr., \& Hanneman, G. J. (1976). The telecommunicationstransportation tradeoff. New York, USA: John Wiley \& Sons.

Onishi, T. (1992). テレワークが都市を変える [Telecommuting changes cities]. Tokyo, Japan: Nikkei Inc.

Premiere Global Services Inc. (2015). 2015 PGi global telework survey. Retrieved April 12, 2017, from http://go.pgi.com/ty-gen -genspec-15telesur-SC1130 
Qvortrup, L. (1998). From teleworking to networking. In P. J. Jackson, \& J. M. Wielen (Eds.), Teleworking: International perspectives (pp. 21-39). London, UK: Routledge.

Sahay, S. (1997). Implementation of information technology: A time-space perspective. Organization Studies, 18(2), 229-260.

Sato, A. (2006). テレワークの社会学的研究 [A sociological study of Telework]. Tokyo, Japan: Ochanomizu-shobo.

Sewell, G., \& Taskin, L. (2015). Out of sight, out of mind in a new world of work?: Autonomy, control, and spatiotemporal scaling in telework. Organization Studies, 36(11), 1507-1529.

Spinks, W. A. (1998). テレワーク世紀 [Telework century]. Tokyo, Japan: The Japan Institute for Labor Policy and Training.

Staples, D. S. (2001). Making remote workers effective. In N. J. Johnson (Ed.), Telecommuting and virtual offices: Issues \& opportunities (pp. 186-212). Pennsylvania, USA: Idea Group.

Taskin, L., \& Devos, V. (2005). Paradoxes from the individualization of Human Resource Management: The case of telework. Journal of Business Ethics, 62, 13-24.

Telework Promotion Conference (1996). テレワーク推進会議最終報告書 [Final report of Telework Promotion Conference] Tokyo, Japan: The Ministry of Posts and Telecommunications

The Minister of Land, Infrastructure, Transport and Tourism (2006). Results of telework population statistics (Actual survey) in 2005. Retrieved August 14, 2007, from http://www.mlit.go.jp/ kisha/kisha06/04/040614_html.

The Minister of Land, Infrastructure, Transport and Tourism (2015). Results of telework population statistics (Actual survey) in 2014. Retrieved May 9, 2016, from http://www.mlit.go.jp/ report/press/toshi02_hh_000046.html.

Thatcher, S. M. B., \& Zhu, X. (2006). Changing identities in a changing workplace: Identification, identity, enactment, self-verification, and telecommuting. Academy of Management Review, 31(4), 1076-1088.

The Telework, Telecottage and Telecentre Association. (1998) The Teleworking Handbook. London, UK: TCA.

Toffler, A. (1980). The third wave. New York, USA: W. Morrow.

Wilson, J. M., O’Leary, M. B., Metiu, A., \& Jett, Q. R. (2008). Perceived proximity in virtual work: Explaining the paradox of far-but-close. Organization Studies, 29(7), 979-1002.

Yamagishi, T. (1998). 信頼の構造 [Structure of trust]. Tokyo, Japan: Tokyo University Publishing.

Yamagishi, T. (1999). 安心社会から信頼社会へ [From the relief society to trust society]. Tokyo, Japan: Chuokoron-shinsya.

Yin, R. K. (1994). Case study research (2 ${ }^{\text {nd }}$ ed.). California, USA: Sage. 